\title{
Earthquake-induced soft-sediment deformation structures in Upper Jurassic open-marine microbialites (Neuquén Basin, Argentina)
}

\author{
Javier Martín-Chivelet ${ }^{\text {a,* }}$, Ricardo M. Palma ${ }^{\text {b }}$, José López-Gómez ${ }^{\text {, }}$, Diego A. Kietzmann ${ }^{\text {b }}$ \\ a Departamento de Estratigrafia, Instituto de Geología Económica (CSIC-UCM), Facuitad de Ciencias Geológicas, Universidad Complutense de Madrid, 28040 Madrid, Spain

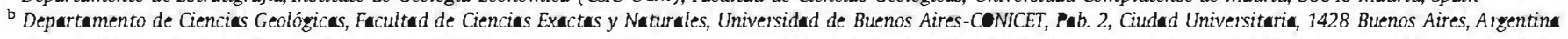

\section{Keywords:}

Soft-sediment deformation

Seismites

Carbonate rocks

Tithonian

Back-arc basin

Andes

\begin{abstract}
A B S T R A C T
Penecontemporaneous decimetre-scale soft-sediment deformation structures are reported from the basal part of the Upper Jurassic-Lower Cretaceous Vaca Muerta Formation, in the Malargüe-Las Leñas area of the back-arc Neuquén Basin (Mendoza Province, Central Andes). The deformed interval (Amarillas bed) is only 0.3 to $0.9 \mathrm{~m}$ thick but occurs in a wide area, larger than $1500 \mathrm{~km}^{2}$. Its age, determined by ammonite biostratigraphy, is Early Tithonian.

The soft-sediment deformation structures were generated in finely laminated, partially consolidated, organicrich, carbonate microbialites that were deposited in open-marine, poorly oxygenated settings, apparently devoid of any significant slope. Those structures include boudins of different sizes and complexity, a variety of folds, normal (listric) dm-scale faults, sub-horizontal detachment surfaces and other features, which are part of several larger-scale, complex slump structures. Deformation was dominantly plastic but near to the ductile-brittle field transition.

On the basis of the observed soft-deformation structures, their geographic distribution, their lateral homogeneity, and the geodynamic framework of the basin in which it was generated, the Amarillas bed can be tentatively attributed to a large, intermediate-depth earthquake that occurred within the plate that subducted beneath the Andean continental margin and the Neuquén back-arc basin.
\end{abstract}

\section{Introduction}

Soft-sediment deformation structures related to earthquakes (i.e., seismites) are often preserved in deposits with contrasting granulometry, such as the alternating sands and argillaceous beds that characterize many alluvial plains, lacustrine environments, coastal and deltaic systems, and turbidite settings (e.g., Ringrose, 1989; Obermeier et al., 1989, 1993; Seth et al., 1990; Alfaro et al., 1997; Enzel et al., 2000; Alfaro et al., 2002; Rossetti and Santos, 2003; Jewell and Ettensohn, 2004; Singh and Jain, 2007; Fortuin and Dabrio, 2008; Perucca et al., 2009). More rarely, they have been described from more homogeneous sediments, such as fine aeolian sands (e.g., Moretti, 2000), sabkha evaporites (Bachmann and Aref, 2005), peritidal carbonates (Kahle, 2002), or lacustrine laminated deposits (e.g., Calvo et al., 1998). However, very little published documentation exists for soft-sediment deformation generated by seismic shocks that affect homogeneous, fine-grained sediments generated in openmarine settings. Characterization of such levels, however, can have a noticeable importance in determining regional seismicity and synsedimentary tectonic activity in depositional settings that are commonly characterized by tectonic quiescence.

In this work we describe examples of soft-sediment deformation structures recognized in open-marine, finely laminated, organic-rich, micritic carbonates of Late Jurassic age, generated in the Neuquén Basin (Central Andes, Argentina). The aims of this paper are 1) to characterize these deformed deposits and their structures, and 2) to document their seismogenic origin and discuss their significance in the geodynamic evolution of the basin.

\section{Geological and stratigraphic framework}

The studied area is located in the so-called Malargüe fold and thrust belt (e.g., Bechis et al., 2008; Giambiagi et al., 2009) in the Central Andes of central-western Argentina (Mendoza Province, Fig. 1). In this area, Andean deformation inverted the Upper Triassic to Lower Cretaceous sequences deposited in the Neuquén back-arc basin (Kozlowski et al., 1993; Manceda and Figueroa, 1995; Giambiagi et al., 2008). The studied stratigraphic interval for soft-sediment deformation is located in those sequences and corresponds to the lower part of the Upper Jurassic-lowermost Cretaceous Vaca Muerta Formation (Fig. 2).

This unit is widely distributed in the Neuquén Basin, and mainly consists of dark bituminous shales, marls, and limestones, which 

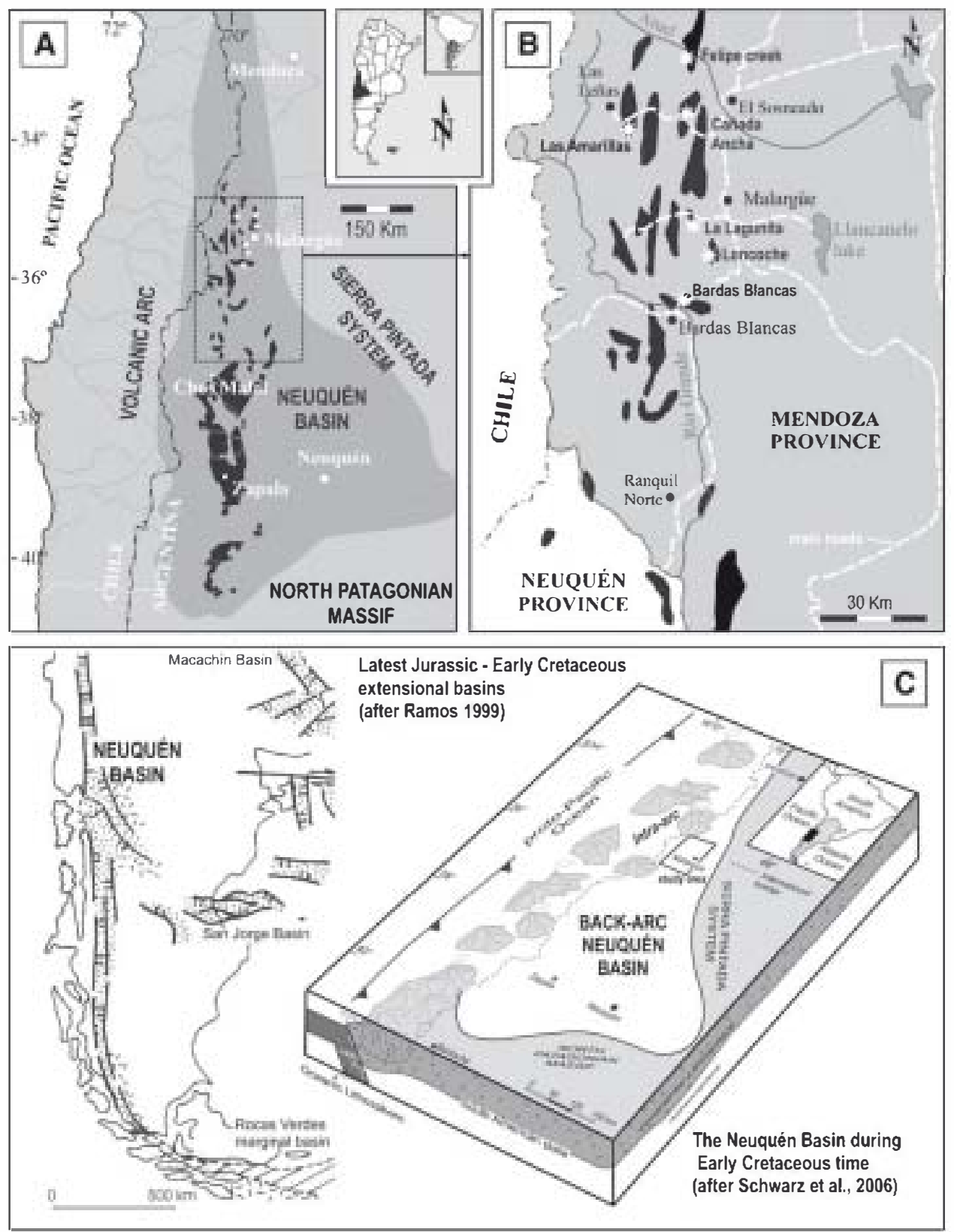

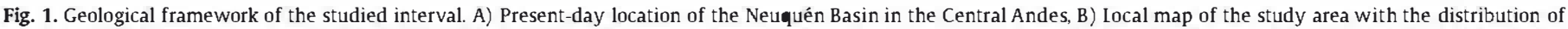

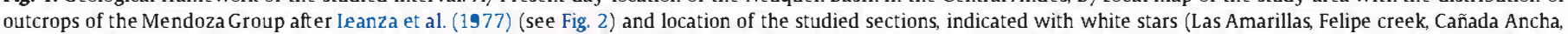

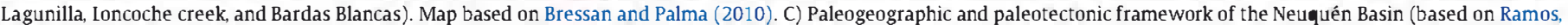
1999 and Schwarz et al., 2006).

characteristically show a markedly cyclic aspect, given by the repetitive succession of couplets of limestone and marlstone/shale. Subordinately and locally, cm- to dm-scale beds of sandstones and calcarenites can locally appear, these being interpreted as turbidite beds (e.g., Leanza et al., 2003) although in some parts they correspond to bottom-current reworked deposits (e.g., Martín-Chivelet et al., 2008). The depositional system is framed within open-marine settings, in which suboxic to anoxic bottom waters prevailed during some intervals (e.g., Doyle et al., 2005; Kietzmann et al., 2008; Kietzmann and Palma, 2009). Also it should be noted that the Vaca Muerta Formation is punctuated with intervals of abundant cm-scale beds of tephra. These latter are easily recognizable because of their white color, clayey nature, homogeneity, and sharp contacts with the host sediment; and they are indicative of volcanic activity in a nearby area. The Vaca Muerta Formation is well-known regionally, as it constitutes one of the most significant hydrocarbon-producing source rocks (e.g., Yrigoyen, 1991; Urien and Zambrano, 1994; Lampe et al., 2006).

The Neuquén Basin includes thick successions of Mesozoic sedimentary rocks $(>6000 \mathrm{~m})$. These overlie the basement of the basin, which consists of Lower Paleozoic to Lower Mesozoic metamorphic, plutonic, volcanic and sedimentary rocks. The basin is located on the western margin of the South American platform and limited by the Andean magmatic arc to the west (Howell et al., 2005) and by a tectonic foreland to the east, between a present-day latitude of $34^{\circ}$ and $41^{\circ} \mathrm{S}$ (such latitude does not differ much from that of the Late Jurassic, Iglesia Llanos, 2008) (Fig. 1). The foreland consisted of the Sierra Pintada belt to the Northeast and the North Patagonian massif to the South. During Jurassic and Cretaceous times, the basin accumulated a relatively continuous sequence, consisting of $>2000 \mathrm{~m}$ 


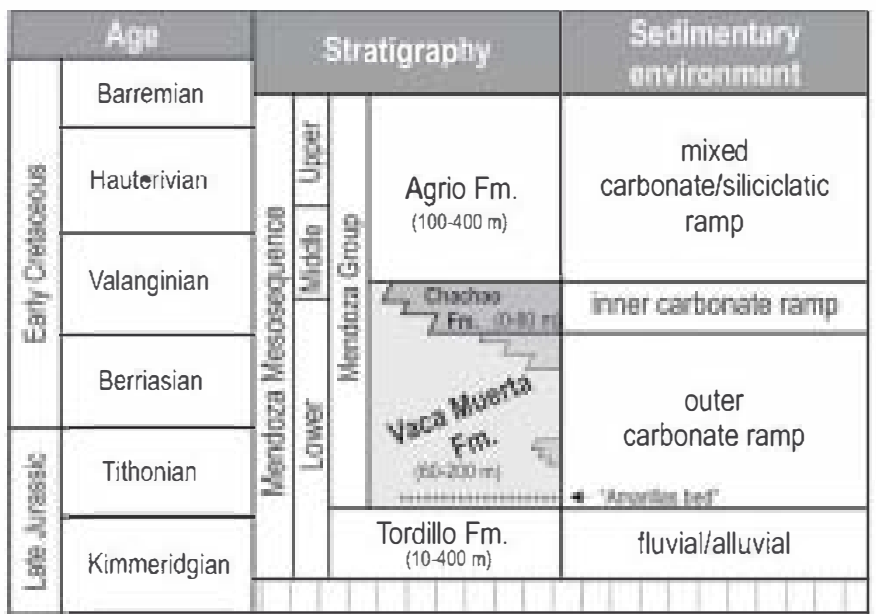

Fig 2. Chronostratigraphic chart of the Kimmeridgian-Barremian units of the study area in the northern part of the Neuquén Basin, showing the stratigraphic location of the Amarillas bed. The thickness of the stratigraphic units in the study area has been added for reference (based in Gulisano and Gutiérrez Pleimling, 1994 and own data).

of alluvial clastics, terrestrial evaporites and marine sediments. Volcanic activity accompanied sedimentation during most of the interval (e.g., Ramos, 1999; López-Gómez et al., 2009a). Some key papers describing the geologic setting of the region are those by Groeber (1946), Digregorio and Uliana (1980), Gulisano et al. (1984), Mitchum and Uliana (1985) and Legarreta and Uliana (1991, 1996).

The basin infill shows a complex geologic evolution which started with a Triassic to Early Jurassic rifting phase related to the continental-scale extension that occurred in the framework of the break-up of Pangea. Later, during Jurassic times, Andean subduction started along the Pacific continental margin. This process induced the generation of a N-S magmatic arc (along the Coast Ranges, from southern Peru to central Chile). Because subduction took place under extensional conditions associated with negative trench roll-back, a series of large extensional back-arc basins, including the Neuquén Basin, formed immediately to the east of the magmatic arc (e.g., Digregorio et al., 1984; Legarreta and Uliana, 1991; Vergani et al., 1995; Legarreta and Uliana, 1996). As a consequence of the activation of new spreading centers in the Central Atlantic during the Jurassic, Andean subduction soon acquired a markedly oblique, SE-directed, component that strongly determined the shape and evolution of the Neuquén Basin (e.g., Zonenshayn et al., 1984; Scheuber et al., 1994; Mpodozis and Ramos, 2008).

\section{Soft-sediment deformation interval: the "Amarillas bed"}

In the lower part of the Vaca Muerta Formation, the soft-sediment deformation is confined almost exclusively to one level, which is only a few decimeters thick, but shows a regional lateral continuity. Six zones covering an area of $\sim 500 \mathrm{~km}^{2}$ (Amarillas Creek, Lagunilla, Cañada Ancha, Felipe Creek, Loncoche Creek and Bardas Blancas) have been investigated in the Malargüe-Las Leñas area in order to characterize this deformed interval. Their locations are shown in Fig. 1.

All the six zones and the corresponding sections were analyzed for soft-sediment deformation structures and sampled for laboratory analyses and ammonite biostratigraphy. Among them, the Amarillas creek section, located a few kilometers west of the little town of Los Molles, exposes an $88 \mathrm{~m}$ thick stratigraphic interval; this offered the best possibilities for a detailed study, with well-developed structures along more than $500 \mathrm{~m}$ of excellent and continuous lateral exposure. In this section, detailed sampling for biochronostratigraphic analysis allowed the sedimentary succession to be placed in the Tithonian. Ammonite biozones include from the Virgatosphinctes mendozanus
Zone (Lower Tithonian) up to the Corongoceras alternans Zone (Upper Tithonian) (Riccardi, pers. commun.).

It should be noted that the good exposure of Vaca Muerta Fm. sediments in the area allows us to infer that this interval of softsediment deformation is a unique event. Other soft-sediment deformation structures appear through the stratigraphic sections (mostly affecting sandy layers towards the top of the unit), but their lateral continuity points towards a local origin.

For all these reasons, the deformed interval herein studied merits detailed, individual examination, and thus it has been informally named the "Amarillas bed". Its main stratigraphic and sedimentological characteristics are the following:

\subsection{Age, stratigraphic control, and regional extension}

In the studied outcrops, the stratigraphic interval containing the Amarillas bed is located in the lowermost part of the Vaca Muerta Formation, where the unit characteristically consists of black shales, laminated microbialites and thin-bedded limestones rich in radiolarians and foraminifers. This basal interval is defined by a sharp contact over the continental clastics of the Tordillo Formation, which usually displays a well-developed ferruginous crust. The Amarillas bed is situated several decimeters above that contact, under- and over-laid by undeformed deposits, which reveal their pervasive horizontal lamination. The bed is 0.2 to $0.8 \mathrm{~m}$ thick and can be traced laterally along hundreds of meters and correlated through tens of kilometers among the four studied areas.

The Vaca Muerta Fm. is rich in ammonite fauna. The Amarillas bed is included, in all the studied outcrops, within the lower part of the V. mendozanus Assemblage Zone (Fig. 2). According to the biostratigraphic ammonoid zonation of the Neuquén Basin, the age of that biozone ranges from the upper part of the Lower Tithonian to the lower part of the Middle Tithonian (Riccardi, 2008), although other authors give it a narrower chronostratigraphic range: the lower (but not lowermost) and middle part of the Lower Tithonian (e.g., Aguirre-Urreta, 2001).

\subsection{Sedimentary facies}

The Amarillas bed consists of thinly laminated, fine-grained limestones, relatively rich in organic matter and showing minor but variable amounts of silt-size clasts and clays (up to 15\%). These limestones form laterally persistent beds with thicknesses of several decimeters (Fig. 3A). The most evident feature is the conspicuous submillimeter- to millimeter-scale, horizontal to sub-horizontal lamination (Fig. 3B). When observed in thin section, this lamination is defined by alternating layers of a) relatively transparent calcite, often internally showing irregular sub-horizontal, wavy to crinkly laminae, which are interpreted as the result of microbially mediated carbonate precipitation; and b) fine-grained wackestones with foraminifers, radiolarians and small peloids, and variable silt-size clastics and clays, interpreted as sediment deposited by settling and later trapped by microbial mats (Fig. 3C). Organic matter can be very abundant in some of these layers, appearing as irregular patches or outlining subhorizontal, very opaque, bands. These laminated facies as a whole can be classified as microbialites (sensu Bume and Moore, 1987).

No evidence of subaerial exposure or relevant reworking by bottom currents is present in such facies. Bioturbation is very poor or absent. Benthic fauna are scarce, represented by occasional small oysters and small and thinly shelled pelecypods. The facies contain other fossils, mostly remains of planktonic or nektonic organisms including abundant ammonite shells (Fig. 3B) and some fish remains. Microfossils include abundant radiolarians and scattered ostracods.

The Amarillas bed microbialites are interpreted to be the result of laterally extensive microbial-mat development, which should take place in a landlocked, sluggish marine floor with suboxic to anoxic 

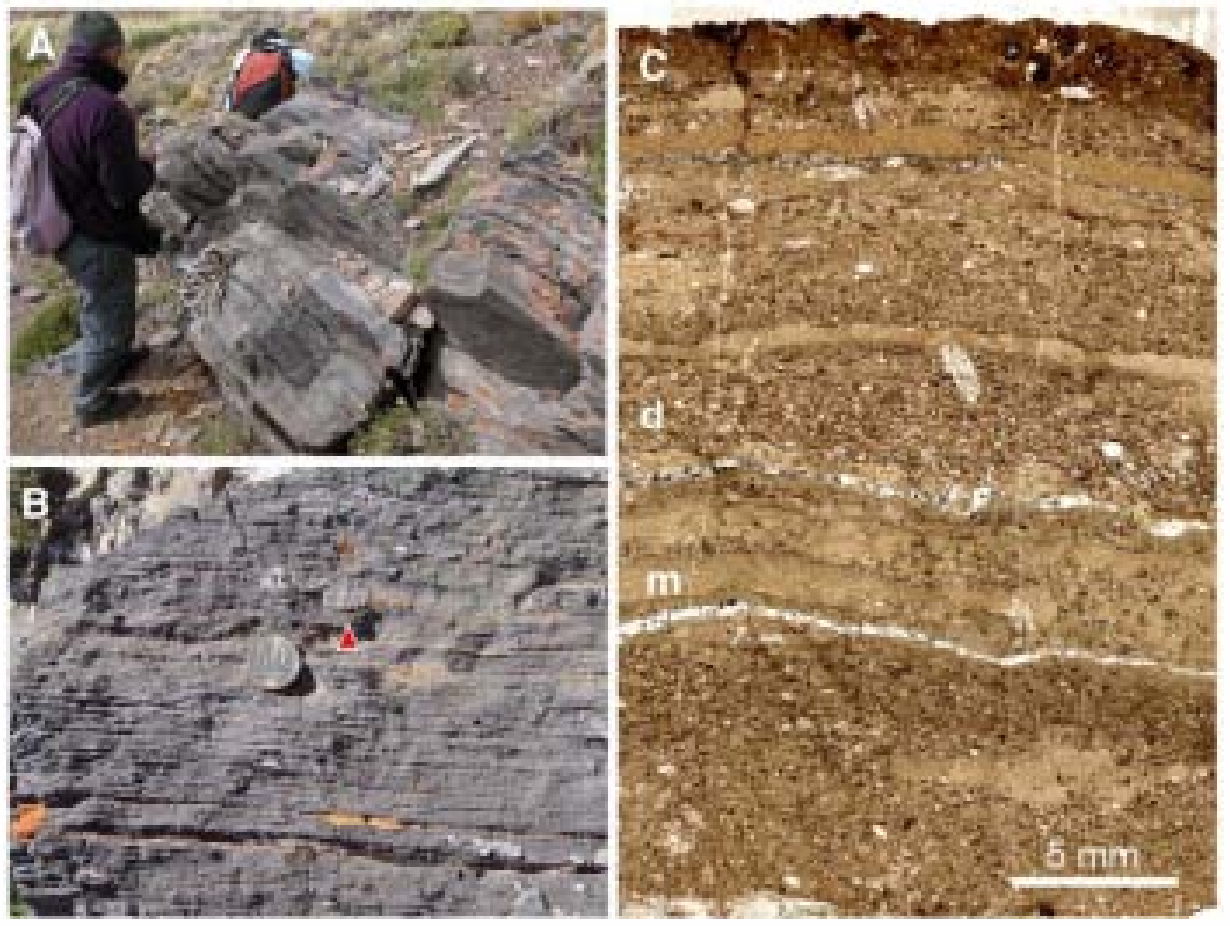

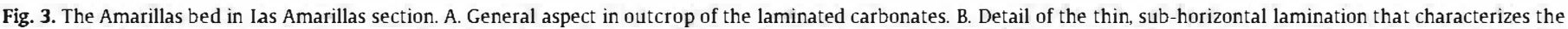

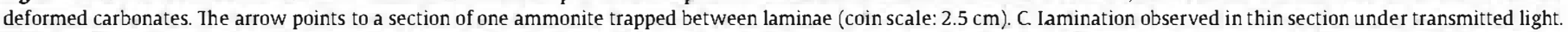

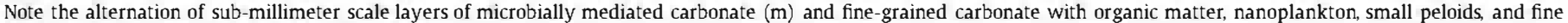
clastics (d). Large crystals are diagenetic in origin.

conditions, at water-depths well below the storm wave base. The organic matter content suggests high organic productivity or good preservation and the absence of bottom-dwelling organisms. The occasional presence of pelecypods can be explained by even slight shifts towards more oxygen content, but still in the dysaerobic zone.

From a paleogeographic perspective, these facies were generated immediately after the abrupt marine transgression that affected the Neuquén basin during the onset of Tithonian time. Such a ransgressive event caused the generalized drowning of the former continental systems.

\section{Soft-sediment deformation structures}

The Amarillas bed, consisting mainly of carbonate microbialites, shows pervasive soft-deformation of lamination. Although deformation ranges from slightly disturbed to strongly distorted, the observed structures reveal the semi-consolidated and coherent nature of the sediment, which allowed preservation of the original lamination. The deformation process was essentially ductile, although evidence of brittle deformation can be also observed.

Soft-sediment deformation structures in the Amarillas bed are cmto dm-scale and rather complex. They include boudins and pinch-andswell structures, normal faults and related structures, microbreccias, recumbent and asymmetrical folds, kink bands and associated folds, and composite structures. All the structures seem to be genetically related, as one passes laterally to others, and thus are the consequence of a common event (or a succession of events very closely related in time). These soft-sediment deformation structures probably are not independent, but represent different parts of larger-scale deformation structures, such as complex slumps. This would explain the coexistence in the deformed interval of extensional features, such as small normal faults, and compressive ones, with a net dominance of folds. The deformed interval as a whole is underlain and overlain by undeformed strata. The main features of the different soft-sediment deformation structures observed in the studied outcrops are the following:

\subsection{Normal faults and donmsagging (Fig. 4)}

Many small normal faults and extensional fractures affect (and are confined to) the Amarillas bed. They are structures in the range of $\mathrm{mm}$ to $\mathrm{dm}$ and include sub-vertical fractures, listric normal microfaults, and small-scale sub-horizontal or low-dipping detachments. All of them die out both upward and downward. In many cases, they are associated with other soft-sediment deformation features, mainly boudinage and pinch-and-swell structures.

In particular, $\mathrm{cm}$ - to dm-scale normal listric faults are common in some intervals (Fig. 4), showing typical dip decrease with depth and associated roll-over anticlines. Locally the normal faults define faultbounded semigraben- and graben-like structures showing downsagging features. Similar structures have been described in seismites developed in different depositional systems (e.g., Seilacher, 1969; Sims, 1975; Seth et al., 1990; Mastalerz and Wojewoda, 1993; Bhattacharya and Bandyopadhyay, 1998; Schneiderhan, 2008).

Microbreccias also occur in the Amarillas bed, forming beddingparallel layers with 1 to $3 \mathrm{~cm}$ thickness, which are usually related to detachment surfaces. The microbreccias are formed by angular and non-sorted $(1 \mathrm{~mm}$ to few $\mathrm{cm}$ ) intraclasts derived from the fragmentation of the laminated facies. Sometimes, brecciation of the original sediment is only partial and is accompanied by ductile deformation. In general, these microbreccias show very little displacement and intraclasts often show matching boundaries. The microbreccia matrix usually consists of sparite cement.

\subsubsection{Interpretation}

Soft-sediment faults, downsagging and microbrecias are subordinated in the Amarillas bed. They indicate that, although there should 

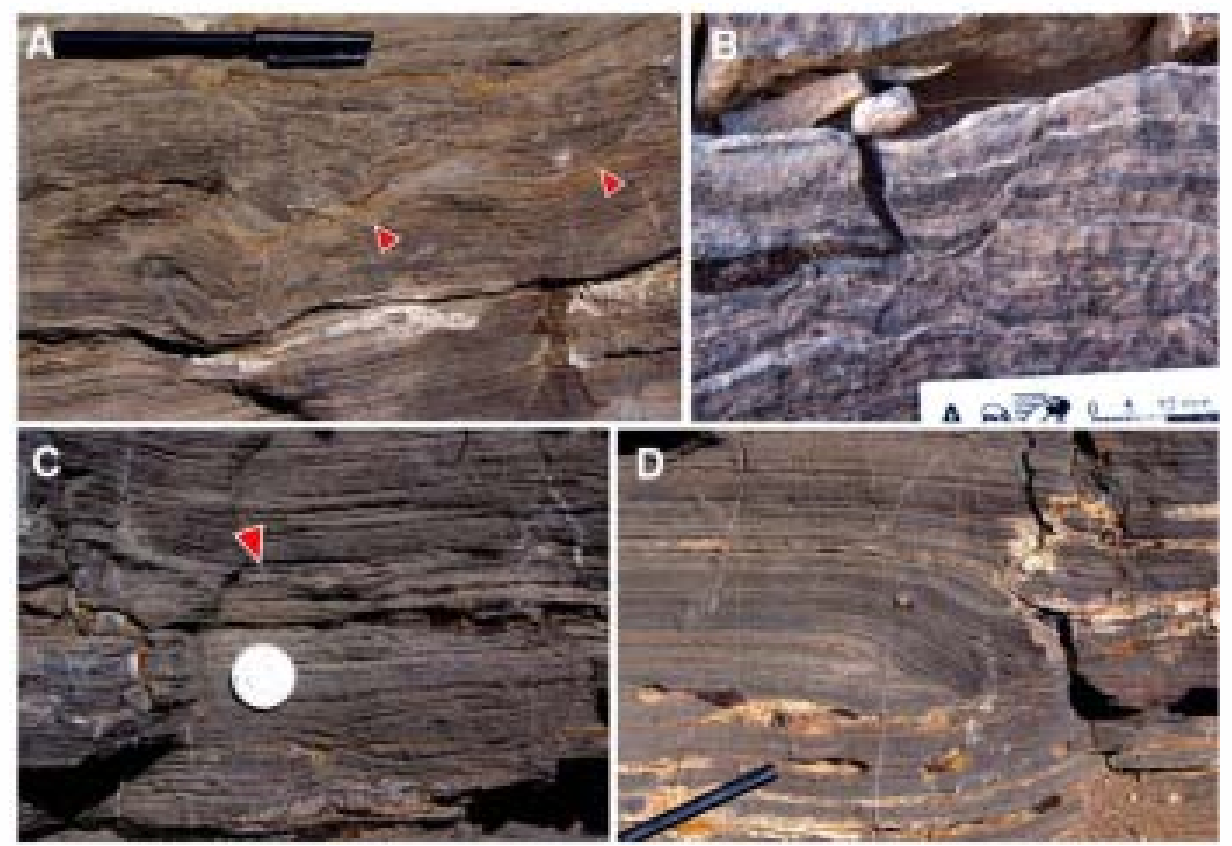

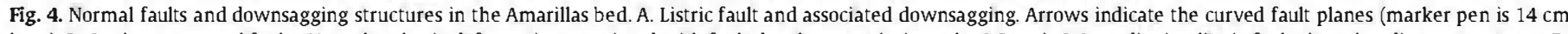

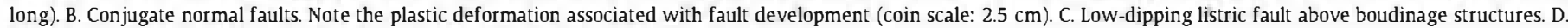
Iow-dipping listric fault. Note that the faulted sediment had previously suffered boudinage.

be a net dominance of hydroplastic processes, brittle deformation also took place and attained importance in some zones or within the deformation interval. It should be noted that some fractures and faults seem to have favored some minor upward migration of water (small fluid escape structures during deformation), although this process seems to have been always very subordinate.

\subsection{Boudinage structures and pinch-and-swell layering (Fig. 5)}

The Amarillas bed frequently displays boudinage structures (sensu Ramberg, 1955). They consist of lateral successions of boudins that affect sets of laminae, which are constricted at lateral intervals. Their sizes are variable, usually cm-scale in height and dm-scale in lateral extent, sometimes reaching more than $15 \mathrm{~cm}$ in height and several decimeters of lateral extent. In all cases, they show rounded ends. These boudinage structures resemble the "loop-bedding" described by Calvo et al. (1998) in Miocene seismites in lacustrine deposits of Spain. The boudinage structures of the Amarillas bed show similar loop morphology (links of a chain); however, they differ in their larger size and more complex patterns. Many boudins are composite (i.e., internally they consist of various smaller boudins vertically piled; Fig. 4). The boudinage structures are often associated with other softsediment deformation structures such as necking of laminae bundles and moderately developed pinch-and-swell layers. Normal faults also appear associated with the boudinage, affecting mainly the ends of the boudins. Some boudins show, internally or at their bases, welldeveloped, nearly horizontal detachment surfaces.

\subsubsection{Interpretation}

Boudinage structures in the Amarillas bed reflect plastic (hydroplastic) deformation of the original, partially lithified microbialites. They are generated by stretching of laminae bundles which show low contrast in competence. Similar structures (but of lesser complexity and size) have been documented mainly from finely laminated lacustrine sediments of several ages (Cole and Picard, 1975; Gibling et al., 1985; Trewin, 1986; Calvo et al., 1998) and interpreted as related to seismic activity under an extensional stress field.

\subsection{Folds (Figs. 6 and 7)}

Folds are the dominant deformation structure in the Amarillas bed. They show a wide variety of shapes and sizes, and their complexity is also strongly variable. They range from slightly deformed layers, defining simple, open, harmonic folds, to strongly contorted layers outlining tight/isoclinal disharmonic ones.

The abundance of asymmetrical folds (including recumbent ones) and overturned beds merits special mention (Fig. 6). They usually configure complex deformational structures, which are several centimeters to a few decimeters high and extend laterally for less than one meter, containing groups of folds. They pass laterally into other deformational features or undeformed intervals. Remarkably, it is always possible to recognize an undeformed base below the complex-fold structure. Sometimes they include small-scale reverse faults and thrusts with well-developed detachment surfaces and some minor sub-vertical fractures. The degree of disruption of the original lamination is generally low and the sediment mixing is minimal, with retention of the original bedding. The often very complicated shapes of these structures do not show any evidence of subsequent flattening (post-slump compaction). This fact suggests rapid increase in viscosity/lithification after the deformation. The asymmetrical folds can show a preferential orientation in a single complex structure, but display a great dispersion when analyzing several ones, separated by only few meters in the same bed and outcrop. The disturbances are essentially "in situ" with an insignificant degree of forward displacement involved in their formation.

In addition to those complex features, the Amarillas bed also shows simpler fold structures. They show rounded hinges and a wide variety of shapes and sizes. They range from slightly deformed layers, defining simple, open, harmonic folds, to strongly contorted ones. Circular and monoclinal shapes are common. Minor faults, associated with the folding, appear occasionally. Along the analyzed exposures, there is not a clear directional component in these fold structures, and apparent opposite directions in the dip of fold axial planes are common, although a detailed, quantitative analysis of these directions has not been done. 

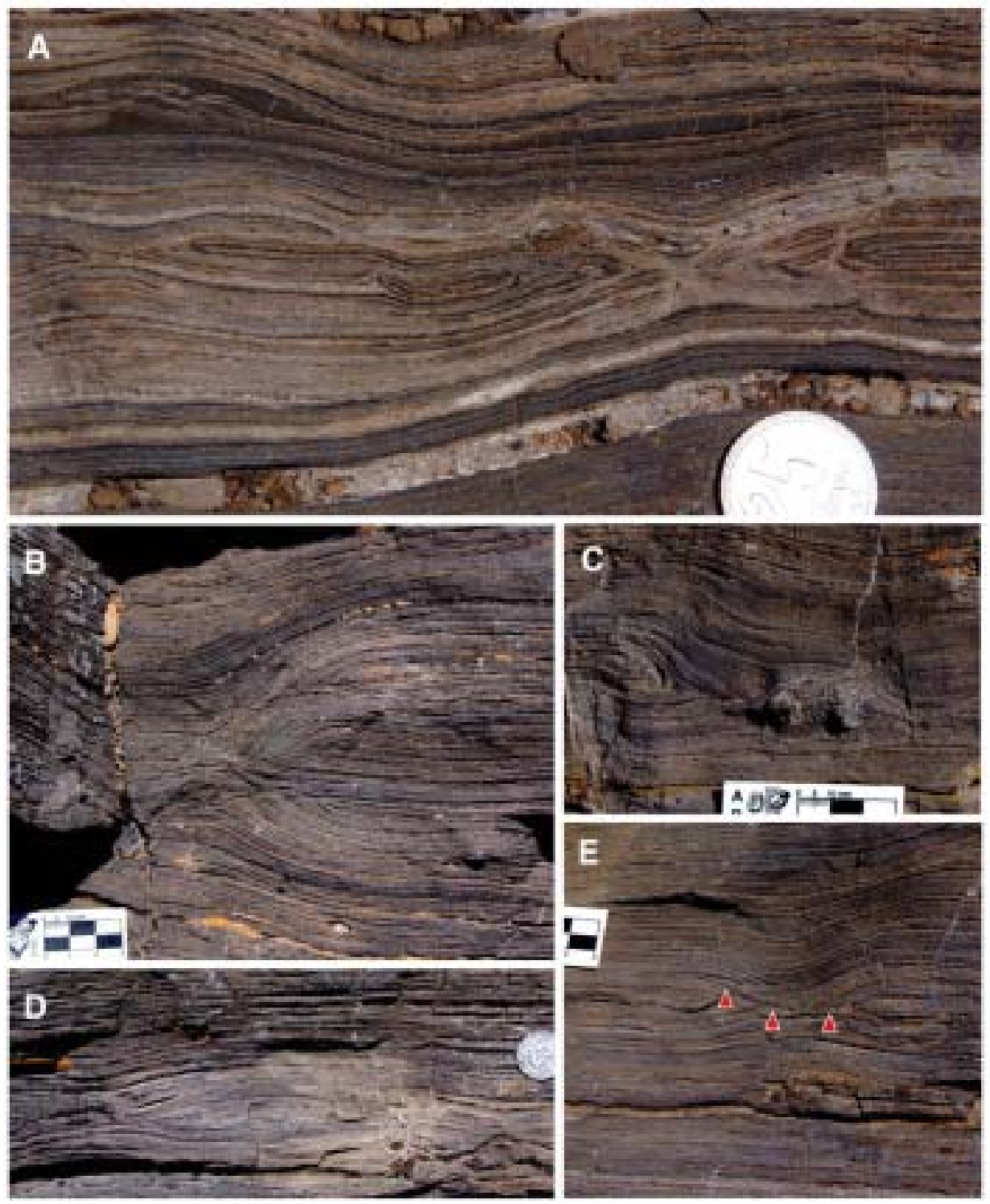

Fig. 5. Examples of boudinage and pinch-and-swell structures in the Amarillas bed (coin diameter is $2.5 \mathrm{~cm}$ ). A. Complex, small-scale boudins. Note the development of small normal faults in the extremities of the boudins. B. Composite boudins and associated pich-and-swell structures. C. Small ammonites between two boudins. D. Medium-scale "sausage-like" structure generated by boudinage. E. Sub-horizontal detachment surface (marked with arrows) developed in association with boudinage.

Much less commonly, the Amarillas bed also shows cm-scale kink bands affecting the microbialites (Fig. 7). They are commonly observed in conjugate pairs, which can define box folds and chevron folds. Such folds form when two or more kink bands merge to form continuous zones of deformation. Although they are in some ways analogous to folds described previously, kink bands and the resulting structures are formed by a simple shear mechanism and represent an alternative shortening mechanism to continuous folding.

\subsubsection{Interpretation}

The complex structures consisting of asymmetrical and overturned folds were developed under a hydroplastic behavior under a quasisolid state. A laminar liquefied flow, which deforms primary bedding without obliterating it (Lowe, 1975) could account for the internal coherence of those complex structures. In the absence of a significant slope, the deformation should start only after a noticeable reduction of the shear strength in the partially consolidated deposits (e.g., Owen, 1987). The weak post-deformation compaction features recognized in the complex-fold structures have been interpreted in some circumstances as evidence of rapid dewatering, contemporaneous with the formation of the slump-like structure (Montenat et al., 2007). However, the type of facies and the practical absence of waterescape structures suggest no substantial dewatering and, on the contrary, a rapid recuperation of viscosity towards the consolidated state by the sediment after deformation. Some similar folded structures have been recognized in seismites of lake sediments (e.g., Marco and Agnon, 1995; Rodríguez-Pascua et al., 2000; Marco and Agnon, 2005; Spalluto et al., 2007). These folded beds, however, differ from those of the Amarillas bed in that they are in clear association with mixed layers (sensu Marco and Agnon, 1995), i.e. stratigraphic levels of limited lateral extent that show a gradual upward transition from the folded bed into fragment-supported and matrix-supported textures between undeformed beds, and whose origin is associated with the activity of synchronous local faults.

Isolated folds in the Amarillas bed also reflect a ductile deforming process, although the common presence of associated reverse microfaults suggests a transitional behavior between brittle and ductile. The different orientation of the axial planes of folds within 

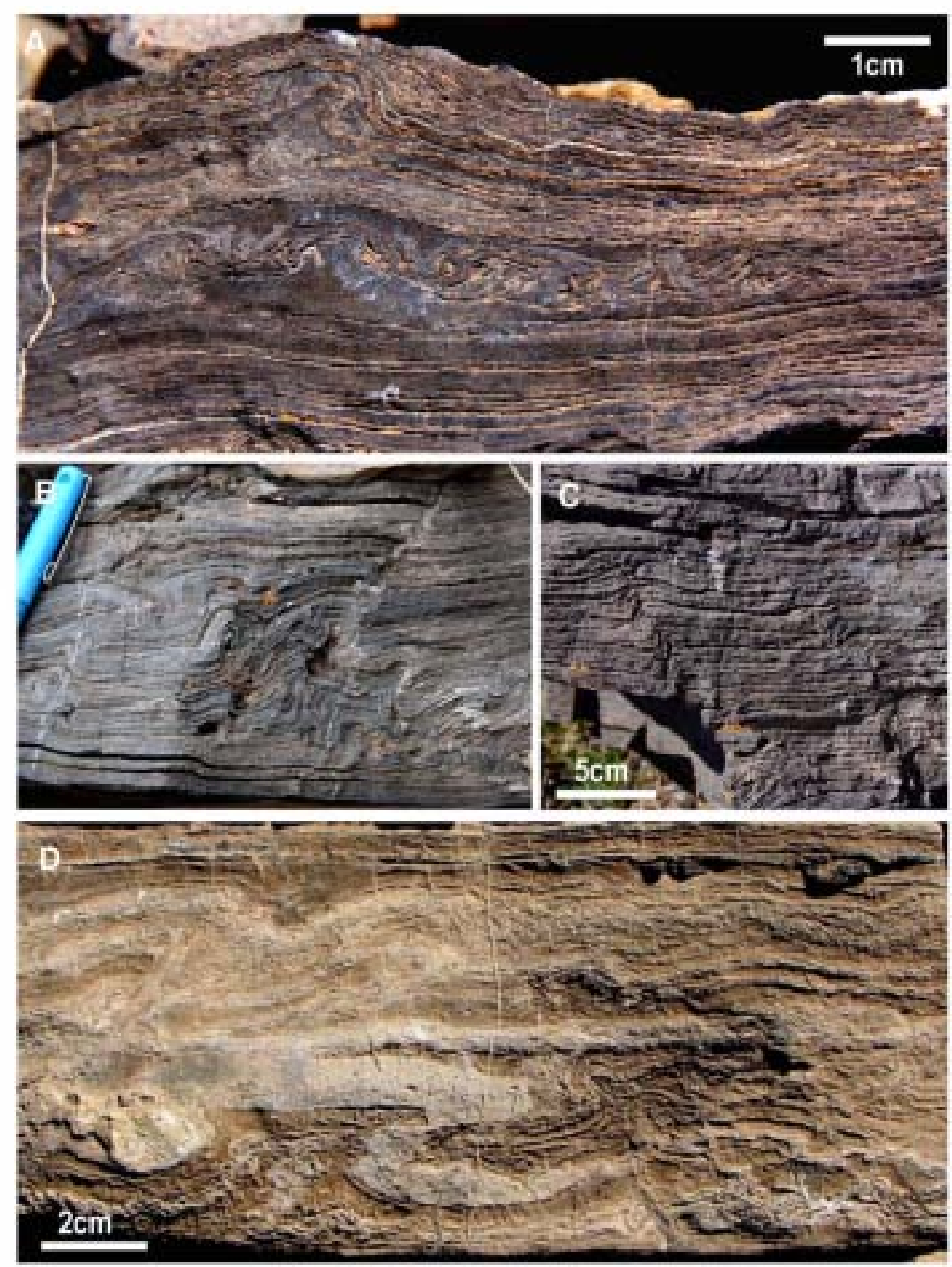

Fig. 6. Examples of slump-like structures, showing complex asymmetrical folds (including recumbent) and overturned beds. See text for explanation.

each outcrop could suggest cyclic shear stress during earthquakes (e.g., Marco and Agnon, 1995; Rodríguez-Pascua et al., 2000; Marco and Agnon, 2005; Rodríguez-López et al., 2007; McCalpin, 2009).

Finally, the presence of kink bands reveals a strong anisotropy in the deformed microbialites. This anisotropy is present in the very thin layers that define the lamination, as is acquired by sediment in a state of relatively high consolidation/lithification, greater than the semiconsolidated state revealed by the formation of the ductile folds and slump-like structures described previously.

\subsection{Composite structures (Fig. 8)}

The soft-sediment deformation structures described above often appear conjointly, forming complex, composite structures that reveal not only a genetic relationship but a succession in their development. These complex structures, such as the one illustrated in Fig. 8, show the following genetic sequence: 1) simple boudins, 2) complex boudins with development of sub-horizontal detachment surfaces, 3) normal fault development (in conjugate pairs and affecting mainly the extremes of the boudins), 4) downsagging, and 5) folding and development of kink bands. Complex folds can also appear within these complex structures, although their position within the timesequence is unclear.

\subsubsection{Interpretation}

The described genetic sequence indicates that the first structures that formed were the boudins, already under conditions of low viscosity and plastic behavior, and under extensional stress. The development of sub-horizontal detachment surfaces, and normal (mostly listric) faults indicates some brittle deformation, indicating that the ductile-brittle transition had been reached. Folding at the end of the deformation process suggests contractional stresses affecting a sediment that already have recovered part of its viscosity. 

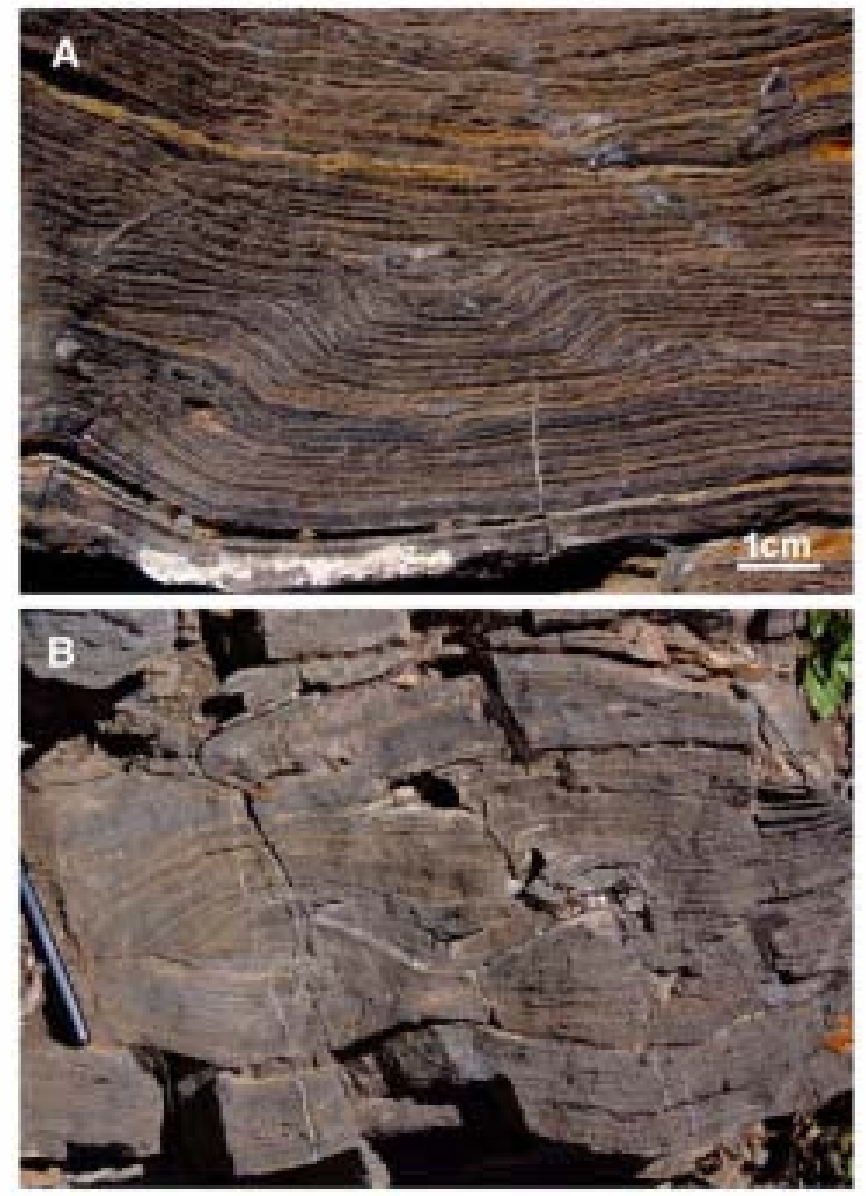

Fig. 7. Folds and kink bands affecting the Amarillas bed. A. Incipient conjugate kink bands and resulting box fold. B. Folds and kink bands affecting previous boudinage structures.

\section{Discussion}

\subsection{Deformation style and its significance}

In the microbialites that form the Amarillas bed in the Vaca Muerta Formation, soft-sediment deformation took place early after sedimentation, when the sediment, always fine-grained, was partially consolidated and had a cohesive behavior. Deformation occurred in finely laminated deposits of microbial origin, on a nearly horizontal surface in a basinal or outer-ramp setting in the Neuquén Basin. In the absence of a well-defined slope, deformation could start only after a drastic reduction of the shear strength of those cohesive sediments. The main deformational features (boudinage, pinch-and-swell structures, and complex folding) indicate that deformation dominantly took place in a hydroplastic way. However, the coexistence of these structures with other brittle ones such as small-scale normal listric faults, fractures, sub-horizontal detachments, kink bands, and microbreccias, suggests that in some cases the deformation occurred in the ductile-brittle field transition. The deformation episode was intense and rapid and, afterwards, the deformed sediment quickly recovered its viscosity and shear strength. This allowed the preservation of all the structures without any subsequent compaction, flattening or collapse. After the event, flat-lying and non-deformed microbialites continued to form, draping the deformed deposits. This indicates that sedimentation recovered its regular setting in a quiet environment without significant disturbances.

Both contractional and extensional structures are present in the Amarillas bed, which is typical of slump structures with extension at the head zone and compression at the toe zone. This coexistence has been commonly described from deformed unconsolidated sediments and frequently interpreted as the result of earthquakes (e.g., Rodríguez-I.ópez et al., 2007), especially when the paleoslope is extremely low, as in the case studied here.

\subsection{Trigger mechanism: seismic shock}

The observed soft-sediment deformation structures and their confinement to the Amarillas bed strongly suggest that the trigger mechanism had an instantaneous nature. Usual trigger factors invoked for soft-sediment deformation in marine settings include seismic shocks and shaking, pressure changes related to storm currents, breaking waves and flood surges, bioturbation, oversteepening, gravitational density flows, and overloading of sediments. From these, earthquake shocks seem the only plausible trigger factor for the Amarillas bed deformations. The combination of the following criteria supports this statement: (1) the deformed interval occurs within basinal microbialites. Deformed beds are under- and overlain by entirely undisturbed horizontal sediments. (2) The deformed interval can be laterally followed in the same outcrop for more than $600 \mathrm{~m}$ (all its length) and regionally correlated over $100 \mathrm{~s} \mathrm{km^{2 }}$. (3) The observed soft-sediment deformation structures indicate that deformation was penecontemporaneous with deposition, with the sediment only partially lithified. (4) Deformation took place in a short time interval, after a drastic reduction of the yield strength, and under a behavior dominantly hydroplastic (but near the ductile-brittle field transition). (5) The duration of the deformable state was very short. (6) The paleoslope of the Amarillas bed was extremely low.

Several authors (e.g., Jones and Omoto, 2000; Moretti, 2000; Spalluto et al., 2007) point to the necessity of discussing the exclusion of all other possible trigger mechanisms before soft-sediment deformation structures could be identified as seismically induced. The reason for this negative approach resides in the well-known fact that many soft-sediment deformation structures can be developed under different causes. For the studied case, however, this discussion is simple and can seem even tautological, as the depositional setting in which the deformed facies were deposited lacks the physical processes that are capable of inducing comparable soft-sediment deformation structures. In particular, the following aspects should be noted: 1) the absence of facies indicating severe storms, 2) the absence of traction processes or evidence of bottom currents, 3) the absence of a significant sedimentary slope to indicate significant gravity sliding or slumping, 4) the absence of significant borrowing, 5) the absence of features related to sudden sediment loading, and 6) the absence of structures indicating abrupt fluid escape.

Two further aspects are commonly discussed in the literature when trying to identify a seismic triggering mechanism for softsediment deformation. These refer to the similarity of the analyzed structures to those reported from 1) well-documented field examples of seismites or 2) laboratory experiments in shaking tables (e.g., Kuenen, 1958; Owen, 1987, 1996; Moretti et al., 1999). In our study, very similar structures to those recorded have been previously shown in field examples of seismically induced deformation and also, in some cases, in laboratory models. However, it should be noted that many structures commonly related to (but not necessarily diagnostic of) seismic activity in the literature are not present (or are very scarce) in the Amarillas bed. These include, among others, mushroom-like structures, flames, well-developed mixed layers, ball-and-pillow structures, sand dikes, sand volcanoes, load structures, pseudonodules and homogenized beds. The reason for these absences is the control that the partially consolidated microbialites exert on deformation. The calcareous, fine-grained material which composes the Amarillas bed is much less prone to liquefaction or fluidization than sediment of greater grain size (e.g., Allen, 1982). The lack of sandy deposits and homogeneity of the deposits also limit the development of density gradients and consequent gravitational instabilities within the 
In the Amarillas bed, the absence of liquefaction/fluidization structures does not seem to be necessarily indicative of a low earthquake magnitude but of the absence of sediments prone to this rheological behavior when submitted to seismic shocks. However the wide lateral extent of the Amarillas bed, and the great homogeneity of its deformational features, points to a large and probably deep earthquake affecting wide areas in the basin.

The Neuquén Basin during the Jurassic behaved as a back-arc basin, in which sedimentation took place under the influence of repeated extensional tectonism. This tectonic activity was concentrated in the Early and Middle Jurassic (e.g., Legarreta and Gulisano, 1989; Bechis et al., 2008), although recent work indicates that extensional fault movements persisted up to the Kimmeridgian (Mescua et al., 2008; López-Gómez et al., 2009b). For the Tithonian, however, no clear evidence of extensional tectonics has been reported. In fact, it is generally assumed that the sedimentation of the Vaca Muerta Formation took place under conditions of relative tectonic quiescence and thermal subsidence (Legarreta and Gulisano, 1989; Gulisano, 1992). The soft-sediment deformation structures of the Amarillas bed cannot be easily correlated to the activity of any fault in the basin.

However, the triggering earthquake could have taken place quite deeply below the basin, within the slab of oceanic lithosphere that subducted beneath the Andean continental margin. In the presentday situation, most earthquakes of western South America are due to strains generated by ongoing subduction of the Nazca plate beneath the South America plate. The subducted Nazca plate is seismically active to depths of about $650 \mathrm{~km}$ (e.g., Barazangi and Isacks, 1976), although most seismic shocks affecting the retroarc areas of the Cordillera are related to intermediate-depth earthquakes (i.e., with focal depths of 70-300 km; e.g., Bolt, 2004). It should be noted that intermediate-depth earthquakes (and also the deep-focus ones, $>300 \mathrm{~km}$ deep) represent deformation within subducted plates, rather than deformation at plate boundaries. They typically cause less damage on the ground surface above their foci than is the case with similar magnitude shallow-focus earthquakes, but large intermediate-depth and deep-focus earthquakes may be felt at much greater distances from their epicenters.

\section{Conclusions}

1. In this work, we describe and interpret examples of soft-sediment deformation structures recognized in open-marine, horizontally laminated, microbialites. These sediments and the deformation structures were generated in the northern part of the Neuquén Basin, a back-arc basin controlled by the oblique subduction occurring at the western margin of Gondwana.

2. The soft-sediment deformation structures are reported from the Amarillas bed, located in the basal part of Vaca Muerta Formation in all the studied outcrops of the Malargüe-Las Leñas area (Mendoza Province). The Amarillas bed is 0.3 to $0.9 \mathrm{~m}$ thick but extends over $1500 \mathrm{~km}^{2}$, and its age has been constrained in all the studied outcrops by ammonite chronobiostratigraphy ( $V$. mendozanus Zone, Early Tithonian). The deformed interval as a whole is underlain and overlain by undeformed strata. Its isochronous nature is also supported by its invariable stratigraphic position in all studied sections.

3. The soft-sediment deformation structures were developed in finely laminated, partially consolidated, calcareous microbialites, deposited in open-marine, poorly oxygenated settings, apparently devoid of any significant slope. These deposits were deformed early after sedimentation.

4. At the time of soft-sediment deformation, the microbialite facies were characterized by high cohesion, high natural shear strength and high sensitivity to plastic or brittle deformation. The integration of fine material and microbial mats probably imparted high cohesion to these deposits from the moment of sedimentation. On the contrary, they were not prone to extensive fluidization.

5. Deformation varies from slightly disturbed to strongly distorted, and includes 1) normal faults, mainly of listric type, and detachment surfaces; 2) boudins and pinch-and-swell structures, showing different degrees of complexity and a variety of sizes and morphologies; 3) a great variety of folding structures, including coherent, non-forward displacing, complex folds; strongly asymmetrical folds and overturned structures; simpler folds with rounded hinges and recumbent shapes showing no obvious preferential orientation; and kink bands and related folds; and 4) composite structures. The dimensions of the observed softsediment deformation structures are in the range of a few centimeters to several decimeters, but they are laterally related and probably constitute different parts of larger structures such as complex slumps, in which zones of contraction (typically the toe zone) and extension (head zone) coexist. The deformation features reveal the semi-consolidated and coherent nature of the sediment, and the deformation process was essentially ductile, although evidence of minor brittle deformation can be also observed. The texture and the rheological characteristics of the microbialites (fine-grained, partially consolidated, and thinly laminated) strongly determined the type of soft-sediment structures and their degree of deformation. These biogenic deposits were not prone to liquefaction or fluidization processes.

6. The sedimentological, stratigraphical, geographical and structural characteristics of the soft-sediment deformation structures that define the Amarillas bed strongly point toward a seismic origin. These characteristics cannot be explained by other mechanisms, including gravitational, hydrodynamical, biological or stratigraphical processes. All the observed deformation is genetically related and the consequence of a common, essentially instantaneous event.

7. On the basis of the observed soft-sediment deformation structures, their wide distribution, their lateral homogeneity, and the geodynamic framework of the basin in which they were generated, the Amarillas bed can be tentatively attributed to a large intermediate-depth earthquake that could have occurred within the plate that subducted beneath the Andean continental margin and the Neuquén back-arc basin.

\section{Acknowledgements}

This research has been done in the framework of the project UBACyT X-476 (Universidad de Buenos Aires) and the research groups 910198 and 910429 (UCM-Comunidad de Madrid, Spain). The Authority of Recursos Naturales de la Provincia de MendozaDelegación Malarguie is thanked for permissions and support during the field work. The authors are especially grateful to Dr. A. Riccardi (Universidad Nacional de La Plata y Museo, Argentina) for ammonite determination, to Dr. J.P. Rodríguez-López (UCM, Madrid) for his friendly comments and discussions on the Amarillas bed. Mr. G. Herrero (UCM, Spain) and Mr. R. Pozuelo (IGE-CSIC, Spain) are thanked for sample preparation and analyses, and Mr. J.C. Poblete for technical assistance in the field. The manuscript benefited from constructive comments and corrections by two anonymous referees and guest editors Dr. P. Alfaro and G. Owen, as well as from English editing by Mr. R Thompson. This is the contribution R-01 of the Instituto de Estudios Andinos Don Pablo Groeber.

\section{References}

Aguirre-Urreta, M.B., 2001. Marine Upper Jurassic-Lower Cretaceous stratigraphy and biostratigraphy of the Aconcagua-Neuquén Basin, Argentina and Chile. Journal of Iberian Geology 27, 71-90. 
Alfaro, P., Moretti, M., Soria, J.M., 1997. Soft-sediment deformation structures induced by earthquakes (seismites) in Pliocene lacustrine deposits (Guadix-Baza Basin, Central Betic Cordillera). Eclogae Geologicae Helvetiae 90, 531-540.

Alfaro, P., Delgado, J., Estevez, A., Molina, J.M., Moretti, M., Soria, J.M., 2002. Liquefaction and fluidisation structures in Messinian storm deposits (Bajo Segura Basin, Betic Cordillera, Southern Spain). International Journal of Earth Sciences 91, 505-513.

Allen, J.R.L., 1982. Sedimentary structures, voL II. Developments in Sedimentology, voL 30B. Elsevier, Amsterdam.

Allen, J.R.L., 1986. Earthquake magnitude-frequency, epicentral distance, and softsediment deformation in sedimentary basins. Sedimentary Geology 46, 67-75

Atkinson, G., 1984. Simple computation of liquefaction probability for seismic hazard applications. Earthquake Spectra 1, 107-123.

Audemard, A., De Santis, F., 1991. Survey of liquefaction structures induced by recent moderate earthquakes. Bulletin of the International Association of Engineering Geology 44, 5-16.

Bachmann, G.H., Aref, M.A.M., 2005. A seismite in Triassic gypsum deposits (Grabfeld Formation, Ladinian), southwestern Germany. Sedimentary Geology 180, 75-89.

Barazangi, M., Isacks, B.L., 1976. Spatial distribution of earthquakes and subduction of the Nazca plate beneath South America. Geology 4, 686-692.

Bechis, F., Giambiagi, L., Yagupsky, D., Cristallini, E., García, V., Mescua, J., 2008. Control of Mesozoic extensional structures on the Andean deformation in the northern Malargüe fold-and-thrust belt, Mendoza, Argentina: 7th International Symposium on Andean Geodynamics (ISAG 2008, Nice), Extended Abstracts, pp. 71-74.

Bhattacharya, H.N., Bandyopadhyay, S., 1998. Seismites in a Proterozoic tidal succession, Singhbhum, Bihar, India. Sedimentary Geology 119, 239-252.

Bolt, B.A., 2004. Earthquakes (5th edition). W.H. Freeman \& Company, New York. 378pp.

Bressan, G.S., Palma, R.M., 2010. Taphonomic analysis of fossil concentrations from Ia Manga Formation (Oxfordian), Neuquén Basin, Mendoza Province, Argentina. Journal of Iberian Geology 36, 55- 71.

Burne, R.V., Moore, L.S., 1987. Microbialites: organosedimentary deposits of benthic microbial communities. Palaios 2, 241-254.

Calvo,J.P., Rodríguez-Pascua, M., Martín-Velázquez, S., Jiménez, S., de Vicente, G., 1998. Microdeformation of lacustrine laminite sequences from Late Miocene formations of SE Spain: an interpretation of loop bedding. Sedimentology 45, 279-292.

Cojan, I., Thiry, M., 1992. Seismically induced deformation structures in Oligocene shallow marine and eolian coastal sands (Paris Basin). Tectonophysics 206, 79-89.

Cole, R.D., Picard, M.D., 1975. Primary and secondary sedimentary structures in oil shale and other fine-grained rocks, Green river Formation (Eocene), Utah and Colorado. Utah GeoL 2, 49-67.

Digregorio, J.H., Uliana, M.A., 1980. Cuenca Neuquina. In: Turner, J.C. (Ed.), Geología Argentina: II Simposio de Geología Regional, Academia Nacional de Ciencias Córdoba, Córdoba, pp. 985-1032.

Digregorio, R.E., Gulisano, C.A., Gutiérrez Plemling, A.R., Minitti, S.A., 1984. Esquema de la evolución geodinámica de la Cuenca Neuquina y sus implicancias paleogeográgicas: Actas II, XX Congreso Geologico Argentino, Bariloche, pp. 147-162.

Doyle, P., Poire, D.G., Spalletti, L.A., Pirrie, D., Brenchley, P., Matheos, S.D., 2005 Relative oxygenation of the Tithonian-Valanginian Vaca Muerta-Chachao formations of the Mendoza Shelf, Neuquén Basin, Argentina. In: Veiga, G.D., Spalletti, L.A., Howell, J.A., Schwarz, E. (Eds.), The Neuquén Basin, Argentina: A Case Study in Sequence Stratigraphy and Basin Dynamics: Special Publications 252, Geological Society of London, London, pp. 185-206.

Enzel, Y., Kadan, G., Eyal, Y., 2000. Holocene earthquakes inferred from a fan-delta sequence in the Dead Sea Graben. Quaternary Research 53, 34-48.

Fortuin, A.R., Dabrio, C. J., 2008. Evidence for Late Messinian seismites, Nijar Basin, south-east Spain. Sedimentology 55 (6), 1595-1622.

Giambiagi, L., Bechis, F., García, V., Clark, A., 2008. Temporal and spatial relationships of thick- and thin-skinned deformation: a case study from the Malargüe fold-andthrust belt, southern Central Andes. Tectonophysics 459, 123-139.

Giambiagi, L., Ghiglione, M., Cristallini, E., y Bottesi, G., 2009. Kinematic models of basement /cover interactions: insights from the Malargüe fold and thrust belt, Mendoza, Argentina. Journal of Structural Geology 31, 1443-1457.

Gibling, M.R., Ukakimaphan, Y., Srisuk, S., 1985. Oil shale and coal in intermontane basins of Thailand. American Association Petroleum Geologists Bulletin 69 (5), $760-766$.

Groeber, P., 1946. Observaciones geológicas a Io largo del meridiano 70. Hoja Chos Malal Revista de la Asociación Geológica Argentina 1, 177-206.

Guiraud, M., Plaziat, J.-C., 1993. Seismites in the fluviatile Bina sandstones: identification of paleoseismes and discussions of their magnitudes in a Cretaceous synsedimentary strike-slips basin (Upper Bennue, Nigeria). Tectonophysics 225 , 493-522.

Gulisano, C.A., 1992. In: Westermann, G.E.G. (Ed.), Paleogeographic evolution of westcentral Argentina: The Jurassic of the Circum-Pacific. Cambridge University Press, pp. 131-146.

Gulisano, C.A., Gutiérrez Pleimling, A.R., 1994. Field Guide. The Jurassic of the Neuquén Basin. b) Mendoza Province. 4th International Congress on Jurassic Stratigraphy ad Geology (Neuquén-Mendoza). Asociación Geológica Argentina, Buenos Aires, $103 \mathrm{p}$

Gulisano, C.A., Gutiérrez Pleimling, A.R., Digregorio, J.H., 1984. Esquema estratigráfico de la secuencia jurásica del oeste de la provincia de Neuquén: Actas LX Congreso Geológico Argentino, San Luís, pp. 221-235.

Hempton, M.R., Dewey, J.F., 1983. Earthquake-induced deformational structures in young lacustrine sediments, East Anatolian Fault, southeast Turkey. Tectonophysics 98, 17-T14

Howell, J.A., Schwarz, E., Spalletti, L.A., 2005. The Neuquén Basin: an overview. In Veiga, G.D., Spalletti, L.A., Howell, J.A., Schwarz, E. (Eds.), The Neuquén Basin,
Argentina: A Case Study in Sequence Stratigraphy and Basin Dynamics: Special Publications 252, Geological Society of Iondon, Iondon, pp. 1-13.

Iglesia Llanos, M.P., 2008. Paleogeografía de América del Sur durante el Jurásico. Revista de la Asociación Geológica Argentina 63, 498-511.

Jewell, H.E., Ettensohn, F.R., 2004. An ancient seismite response to Taconian far-field forces: the Cane Run Bed, Upper Ordovician (Trenton) Lexington. Journal of Geodynamics 37, 487-511.

Jones, A.P., Omoto, K., 2000. Towards establishing criteria for identifying trigger mechanisms for soft-sediment deformation: a case study of Iate Pleistocene lacustrine sands and clays, Onikobe and Nakayamadaira Basins, northeastern Japan. Sedimentology 47, 1211-1226.

Kahle, C.F., 2002. Seismogenic deformation structures in microbialites and mudstones, Silurian Lockport Dolomite, northwestern Ohio, U.S.A. Journal of Sedimentary Research 72 (1), 201-216.

Kietzmann, D.A., Palma, R.M., 2009. Taf of acies y biofacies de Formación Vaca Muertaen el sector surmendocino de la Cuenca Neuquina: implicancias paleoecológicas, sedimentológicas y estratigráficas. Ameghiniana 46 (2), 321-343.

Kietzmann, D.A., Palma, R.M., Bressan, G.S., 2008. Facies y microfacies de la rampa tithoniana-berriasiana de la Cuenca Neuquina (Formación Vaca Muerta) en la sección del arroyo Ioncoche-Malargüe, provincia de Mendoza. Revista Asociación Geológica Argentina 63, 696-713.

Kozlowski, E., Manceda, R., Ramos, V.A., 1993. Estructura. In: Ramos, V. (Ed.), Geologíay recursos naturales de Mendoza, Relatorio: $12^{\circ}$ Congreso Geológico Argentino y $2^{\circ}$ Congreso Exploración de Hidrocarburos, pp. 235-256.

Kuenen, P.H., 1958. Experiments in geology. Transactions of the Geological Society of Glasgow 23, 1-26.

Lampe, C., Kornpihl, K., Sciamanna, S., Zapata, T.,Zamora, G., Varadé, R., 2006. Petroleum systems modeling in tectonically complex areas-a 2D migration study from the Neuquén Basin, Argentina. Journal of Geochemical Exploration 89, 201-204.

Leanza, H.A., Marchese, H.G., Riggi, J.C., 1977. Estratigrafía del Grupo Mendoza con especial referencia a la Formación Vaca Muerta entre los Paralelos $35^{\circ}$ y $40^{\circ}$ Ls. Cuenca Neuquina-Mendocina. Revista de la Asociación GeológicaArgentina 32 (3), $190-208$.

Leanza, H.A. Hugo, CA., Repol, D., Salvarredy Aranguren, M., 2003. Miembro Huncal (Berriasiano inferior): un episodio turbidítico en la Formación Vaca Muerta, Cuenca Neuquina, Argentina. Revista de la Asociación Geológica Argentina58 (2), 248-254.

Legarreta, L., Gulisano, C.A., 1989. Análisis estratigráfico secuencial de la Cuenca Neuquina (Triásico superior- Terciario inferior, Argentina). In: Chebli, G., Spalletti, L.A. (Eds.), Cuencas Sedimentarias Argentina: Serie Correlación Geológica, 6. Universidad Nacional de Tucumán, Tucumán, pp. 221-243.

Legarreta, L., Uliana, M.A., 1991. Jurassic-Cretaceous Marine Oscillations and Geometry of Back Arc Basin, Central Argentina Andes. In: McDonald, D.I.M. (Ed.), Sea level changes at active plate margins: Process and product: Special Publication, 12. International Association of Sedimentologist, Oxford, pp. 429-450.

Legarreta, L., Uliana, M.A., 1996. The Jurassic succession in west central Argentina: stratal patterns, sequences, and paleogeographic evolution. Palaeogeography, Palaeoclimatology, Palaeoecology 120, 303-330.

López-Gómez,J., Martín-Chivelet,J., Palma, R.M., 2009a. Architecture and development of the alluvial sediments of the Upper Jurassic Tordillo Formation in the Cañada Ancha Valley, northern Neuquén Basin, Argentina. Sedimentary Geology 219 , $180-195$.

López-Gómez, J., Palma, R.M., Martín-Chivelet, J., 2009b. Rapid lateral changes significance in the continental environments of the Upper Jurassic Tordillo Fm. Northern Neuquén Basin, Argentina: 27th IAS meeting, AIghero, Italy, Book of Abstracts, p. 593.

Lowe, D.R., 1975. Water escape structures in coarse-grained sediments. Sedimentology 22, 157-204.

Manceda, R., Figueroa, D., 1995. Inversion of the Mesozoic Neuquén rift in the Malargüe fold-thrust belt, Mendoza, Argentina. In: Tankard, A.J., Suárez, R., Welsink, H.J (Eds.), Petroleum Basins of South America: AAPG Memoir, 62, pp. 369-382.

Marco, S., Agnon, A., 1995. Prehistoric earthquake deformations near Masada, Dead Sea graben. Geology 23, 695-698.

Marco, S., Agnon, A., 2005. High-resolution stratigraphy reveals repeated earthquake faulting in the Masada Fault Zone, Dead Sea Transform. Tectonophisics 408, 101-112.

Martín-Chivelet, J., Fregenal Martínez, MA, Chacón, B, 2008. Traction sedimentary structures in contourites. In: Rebesco, M., et aL (Ed.), Contourites: Developments in Sedimentology, 60. Elsevier, Amsterdam, pp. 159-183.

Mastalerz, K.,Wojewoda,J., 1993. Alluvial-fan sedimentation along an active strike-slip fault: Plio-Pleistocene PreKaczawaf an, Sw Poland. Special Publication International Association Sedimentologist 17, 293-304.

McCalpin, J., 2009. Paleoseismology, Second Edition. Academic Press, San Diego. 613pp.

Mescua, J.F., Giambiagi, L.B., Bechis, F., 2008. Evidencias de tectónica extensional en el Jurásico Tardío (Kimeridgiano) del suroeste de la provincia de Mendoza. Revista de la Asociación Geológica Argentina 63, 512-51

Mitchum, R.M., Uliana, M.A., 1985. Seismic stratigraphy of carbonate depositional sequences, Upper Jurassic-Lower Cretaceous. Neuquén Basin, Argentina. In: Berg, R.B., Woolverton, D.G. (Eds.), Seismic Stratigraphy: an integrated Approach to Hydrocarbon Exploration: AAPG, Memoir, 39, pp. 255-274.

Montenat, C., Barrier, P., Ott d'Estevou, P., Hibsch, C., 2007. Seismites: an attempt at critical analysis and classification. Sedimentary Geology 196, 5-30.

Moretti, M., 2000. Soft-sediment deformation structures interpreted as seismites in middle-late Pleistocene aeolian deposits (Apulian foreland, southern Italy). Sedimentary Geology 135 , 167-179.

Moretti, M., Alfaro, P., Caselles, O., Canas, J.A., 1999. Modelling seismites with a digital shaking table. Tectonophysics 304, 369-383. 
Mpodozis, C., Ramos, V.A., 2008. Tectónica jurásica en Argentina y Chile: extensión, subducción oblicua, rifting, deriva y colisiones? Revista de la Asociación Geológica Argentina 63 (4), 481-497.

Obermeier, S.F., Jacobson, R.B., Smott, J.P., Weems, R.E., Gohn, G.S., Monroe, J.E. Powards, D.S., 1989. Earthquake-induced liquefaction features in the coastal setting of South Carolina and the fluvial setting of the New Madrid seismic zone: United States Geological Survey Professional Paper 1504, p. 44.

Obermeier, S.F., Martin, J.R., Frankel, A.D., Youd, T.L., Munson, P.J., Munson, C.A., Pond, E.C., 1993. Liquefaction evidence for one or more strong Holocene earthquakes in the Wabash Valley of Southern Indiana and Illinois, with a preliminary estimate of magnitude: United States Geological Survey Professional Paper 1536, p. 27

Owen, G., 1987. Deformation processes in unconsolidated sands. In: Jones, M.E. Preston, R.M.F. (Eds.), Deformation of Sediments and Sedimentary Rocks: Geological Society Special Publication, 29, pp. 11-24

Owen, G., 1996. Experimental soft-sediment deformation: structures formed by the liquefaction of unconsolidated sands and some ancient examples. Sedimentology 43, 279-293.

Perucca, L.P.,Bracco, A.I., Moreiras, S.M., 2009. Determination of seismogenic structures and earthquake magnitude from seismites in the Acequion river, Precordillera Range, central-western Argentina. Journal of Iberian Geology 35 (1), 5-18.

Ramberg, H., 1955. Natural and experimental boudinage and pinch-and-swell structures. Journal of Geology 63, 512-526.

Ramos, V.A., 1999. Rasgos estructurales del territorio argentino. In: Caminos, R. (Ed.) GeologíaArgentina: Anales 29, Instituto de Geología y Recursos Minerales, Buenos Aires, pp. 715- 784

Riccardi, A.C., 2008. El Jurásico de la Argentina y sus amonites. Revista de la Asociación Geológica Argentina 63 (4), 625-643.

Ringrose, P.S., 1989. Palaeoseismic (?) liquefaction event in late Quaternary lake sediment at Glen Roy, Scotland. Terra Nova 1, 57-62.

Rodríguez-López, J.P., Liesa, C.L., Meléndez, N., Soria, A.R., 2007. Normal fault development in a sedimentary succession with multiple detachment levels: the Lower Cretaceous Oliete sub-basin, Eastern Spain. Basin Research 19 (3), 409-435

Rodríguez-Pascua, M.A., Calvo,J.P., De Vicente, G.,Gómez-Gras, D., 2000. Soft-sediment deformation structures interpreted as seismites in lacustrine sediments of the Prebetic Zone, SE Spain, and their potential use as indicators of earthquake magnitudes during the Iate Miocene. Sedimentary Geology 135, 117-135.

Rossetti, D.F., Santos Jr., A.E., 2003. Events of sediment deformation and mass failure in Upper Cretaceous estuarine deposits (Cametá Basin, northern Brazil) as evidence for seismic activity. Sedimentary Geology 161, 107-130.
Scheuber, E., Bogdanic, T., Jensen, A., Reutter, K.-J., 1994. In: Reutter, K.-J., Scheuber, E., Wigger, P.J. (Eds.), Tectonic development of the North Chilean Andes in relation to plate convergence and magmatism since the Jurassic: Tectonics of the Southern Central Andes, Structure and evolution of an active continental margin. SpringerVerlag, Berlin, pp. 121-139.

Schneiderhan, E.A., 2008. Neoarchaean clastic rocks on the Kaapvaal Craton : provenance analyses and geotectonic implications. PhD Thesis, University of Johannesburg. http://hdLhandle.net/10210/853.

Schwarz, E., Spalletti, L.A., Howell, J.A., 2006. Sedimentary response to a tectonically induced sea-level fall in a shallow back-arc basin: the Mulichinco Formation (Lower Cretaceous), Neuqu?n Basin, Argentina. Sedimentology 56, 53-81.

Seilacher, A., 1969. Fault graded beds interpreted as seismites. Sedimentology 13 , $155-159$

Seth, A., Sarkar, S., Bose, P.K., 1990. Synsedimentary seismic activity in an immature passive margin basin (Iower Member of the Katrol Formation, Upper Jurassic, Kutch, India). Sedimentary Geology 68, 279-291.

Sims, J.D., 1975. Determining earthquake recurrence intervals from deformational structures in young lacustrine sediments. Tectonophysics 29, 144-152.

Singh, S., Jain, A.K., 2007. Liquefaction and fluidization of lacustrine deposits from Lahaul-Spiti and Iadakh Himalaya: geological evidences of paleoseismicity along active fault zone. Sedimentary Geology 196, 47-57.

Spalluto, L., Moretti, M., Festa, V., Tropeano, M., 2007. Seismically-induced slumps in Lower-Maastrichtian peritidal carbonates of the Apulian Platform (southern Italy). Sedimentary Geology 196, 81-98.

Trewin, N.H., 1986. Sedimentology and palaeontology of the Achanarras fish bed of the Middle Old Red Sandstone, Scotland. Transactions of the Royal Society of Edinburg: Earth Sciences 77, 21-46

Urien, C.M., Zambrano, J.J., 1994. Petroleum systems in the Neuquén Basin, Argentina. In: Magoon, L.B., Dow, W.G. (Eds.), The Petroleum System-From Source to Trap: American Association of Petroleum Geologists Memoir, voL 60, pp. 513-534.

Vergani, G.D., Tankard, A.J., Belotti, H.J., Welsink, H.J., 1995. Tectonic evolution and paleogeography of the Neuquén Basin, Argentina. In: Tankard, A.J., Suarez, R., Welsink, H. (Eds.), Petroleum Basins of South America: American Association of Petroleum Geologists Memoir, voL 62, pp. 383-402.

Yrigoyen, M.R., 1991. Hydrocarbon resources of Argentina: World Petroleum Congress 13, Petrotecnia Special Issue, pp. 38-54

Zonenshayn, L.P., Savostin, L.A., Sedov, A.P., 1984. Global paleogeographic reconstructions for the last 160 million years. Geotectonics $18,181-195$ 